\title{
EFEKTIVITAS KEPEMIMPINAN KEPALA MADRASAH SEBAGAI PENGAMBIL KEPUTUSAN
}

\author{
Saifan Irwan \\ Kepala Madrasah Aliyah Negeri 2 Aceh Barat \\ E-mail: saifanirwan@gmail.com
}

\begin{abstract}
Abstrak
Pengambilan keputusan merupakan salah satu permasalahan dari sekian banyak permasalahan yang dihadapi oleh seorang Pemimpin, terlebih lagi dalam memimpin suatu lembaga pendidikan di Madrasah. Efektifitas kepemimpinan kepala madrasah sangat menentukan kemajuan madrasah kedepan dengan berbagai pertimbangan yang harus dipikirkan untuk mendapatkan solusi terhadap permasalahan komplek yang muncul dalam suatu lembaga yang dipimpinnya. Pengambilan keputusan adalah bagian terpenting dalam merencanakan kegiatan. Suatu keputusan yang diambil kemungkinan berdampak pada penyelesaian masalah atau justru sebaliknya menambah masalah baru. Tulisan ini akan menganalisis bagaimana efektifitas kepemimpinan kepala madrasah sebagai manager dalam pengambilan keputusan yang baik yang akan berdampak terhadap kemajuan madrasah ke depan.
\end{abstract}

Kata Kunci: Efektifitas kepemimpinan, Pengambilan Keputusan, Kepala Madrasah

\begin{abstract}
Decision-making is one of the many problems a leader faces, especially when running an educational institution in Madrasah. The effectiveness of the madrasa director's leadership largely determines the future progress of the madrasa with various considerations that must be taken into account in order to find solutions to complex problems that arise in an institution he leads. Decision making is the most important part of planning activities. A decision made can have an impact on the solution of problems or, on the contrary, add new problems. This paper will analyze the effectiveness of the madrasa director's leadership as a manager in making good decisions that will affect the progress of the madrasa in the future.
\end{abstract}

Keywords: Effectiveness of Leadership, Decision Making, Head of Madrasa 


\section{PENDAHULUAN}

Pendidikan Islam di Indonesia merupakan warisan peradaban Islam dan sekaligus aset bagi pembangunan pendidikan nasional. Sebagai warisan, ia merupakan amanat sejarah untuk dipelihara dan dikembangkan oleh umat Islam dari masa ke masa. Sedangkan sebagai aset, pendidikan Islam yang tersebar di berbagai wilayah ini membuka kesempatan bagi bangsa Indonesia untuk menata dan mengelolanya sesuai dengan sistem pendidikan nasional.

Madrasah merupakan bagian dari pranata pendidikan yang memiliki ciri khas dan berakar kuat pada sendi-sendi nilai dan budaya yang dikembangkan masyarakat. Tidak berlebihan jika dikatakan bahwa madrasah telah menjadi salah satu wujud budaya Indonesia.

Namun dalam perkembangannya kemudian, lembaga pendidikan populis ini telah mengalami proses modernisasi yang berlangsung secara terus menerus. Nampaknya ada pergeseran paradigma yang tidak dapat dihindari di kalangan masyarakat madrasah, terutama dalam kerangka memenuhi kebutuhan dan tuntutan perubahan kehidupan masyarakat di era global. Secara perlahan namun pasti, madrasah berupaya mengadaptasi tuntutan tersebut.

Persoalannya, modernisasi madrasah, meskipun telah berlangsung puluhan tahun, belum juga mampu mengantarkan madrasah pada gerbang perubahan yang signifikan, misalnya dibanding lembaga sekolah. Alih-alih menghasilkan lulusan yang qualified, malah hingga kini kesan stigmatik itu tak juga hilang; manakala menyebut madrasah, maka yang tergambar adalah sekolah yang kurang maju dan sangat lamban (untuk tidak menyebut sulit) menerima ide-ide pembaruan. Sebagai bukti paling gamblang, seiring dengan upaya di atas, internal madrasah sendiri pada kenyataannya tetap saja menyisakan kerumitan persoalan yang membenang kusut, mulai dari dana minim, manajemen "apa adanya", sarana prasarana tidak mencukupi, tenaga guru yang mis-match dan under qualified "dilengkapi" honor yang tidak masuk akal, hingga mutu lulusan yang rendah.( Nunu Ahmad An-Nahidl, dkk, 2017:2) Permasalahan lain yang dihadapi madrasah dalam era otonomi daerah adalah perlakuan pemerintah daerah yang tidak adil dan cenderung mengabaikan.

Dikeluarkannya SK Mendagri No. 903/2429/SJ tentang Pedoman Penyusunan APBD Tahun Anggaran 2006 yang pada lampiran 2 menyebutkan bahwa pengalokasian anggaran APBD diperuntukkan membantu institusi vertikal dalam melaksanakan tugas dan fungsinya di daerah tidak diperbolehkan ( Imran Siregar, 2007:3).

Dari uraian di atas menunjukkan pentingnya sebuah kepemimpinan yang efektif di madrasah karena kepemimpinan merupakan fungsi inti dan aktifitas Manajemen di madrasah. Di pundak pemimpin, aktifitas perencanaan, pengorganisasian, pemantauan dan lain sebagainya bisa berjalan dengan baik. Kepala madrasah yang berfungsi sebagai pemimpin madrasah secara manajerial dituntut untuk mampu mengelola madrasah yang dipimpinnya agar madrasah tersebut berkembang dan memperoleh kemajuan dari waktu ke waktu. Kepala madrasah dituntut mampu menggerakkan guru secara efektif, membina hubungan baik antar mereka agar tercipta suasana yang positif, bergairah, produktif, dan kompak. Demikian pula kepala madrasah dituntut memiliki kemampuan untuk membina segenap warga madrasah agar dapat mendukung penumbuhan kreatifitas, disiplin, dan semangat belajar siswa yang tinggi. Dengan demikian kepala madrasah merupakan motor penggerak bagi sumber daya madrasah sehingga seringkali disebut sebagai penentu sukses tidaknya kegiatan madrasah. Dengan kata lain, kualitas madrasah ditentukan oleh kualitas kepemimpinan kepala madrasah, terlebih dalam penerapan pendekatan manajemen berbasis sekolah.

Madrasah dengan pendekatan manajemen berbasis sekolah adalah bentuk madrasah yang salah satunya ditandai dengan kepemimpinan kepala madrasah yang kuat dalam mengkoordinasikan, menggerakkan, menyerasikan segenap sumber daya yang tersedia. Kepala madrasah bertanggungjawab untuk mendorong madrasah mewujudkan 
visi, misi, tujuan dan sasaran madrasah melalui berbagai program yang direncanakan dengan matang, bertahap sesuai potensi serta terlaksana dengan baik sesuai dengan rencana. Oleh karena itu, sangatlah masuk akal bila kepala madrasah dituntut memiliki kemampuan manajemen dan kepemimpinan yang memadai agar mampu mengambil inisiatif dan menumbuhkan kreatifitas guna meningkatkan mutu pendidikan di madrasah.

Pentingnya sebuah kepemimpinan yang efektif di madrasah ini diperkuat oleh Dirjen Pendis (Pendidikan Agama Islam) Departemen Agama Republik Indonesia, Prof. Dr. Mohammad Ali dengan mengatakan bahwa kunci memacu kualitas madrasah terletak pada pemimpin dan pengelola lembaga yang bersangkutan (Mohammad Ali, 2011:8).

Orang yang memiliki locus of control (orientasi pusat kendali) internal yang kuat yakin bahwa peristiwa dalam hidup mereka lebih banyak ditentukan oleh tindakan mereka sendiri daripada oleh kebetulan atau kekuatan yang tidak dapat dikendalikan. Sebaliknya, orang yang memiliki orientasi kendali eksternal yang kuat yakin bahwa peristiwa yang terjadi kebanyakan ditentukan oleh suatu kebetulan atau nasib dan mereka tidak dapat berbuat apapun untuk memperbaiki hidup mereka.

Mereka lebih banyak mengambil inisiatif daripada para eksternal dalam menentukan dan memecahkan masalah. Mereka percaya dengan kemampuannya untuk mempengaruhi orang dan lebih banyak kemungkinannya akan menggunakan bujukan daripada taktik mempengaruhi yang memaksa atau manipulatif. Mereka akan lebih fleksibel, lebih adaptif, dan inovatif dalam menanggapi masalah dan dalam strategi manajemennya. Jika terjadi kemunduran atau kegagalan, mereka memilih untuk introspeksi dan belajar dari hal tersebut daripada hanya menganggapnya sebagai sebuah nasib buruk.

Faktor lain yang juga berkaitan erat dengan efektivitas kepemimpinan adalah kemampuan dan kemahirannya dalam mengambil keputusan. Para Kepala madrasah saat ini menghadapi persoalan bagaimana menyikapi otonomi di bidang pendidikan dengan ragam problem yang menyertainya. Untuk memberdayakan kepala madrasah, konsekuensinya dengan memperluas pengetahuan dan ketrampilan pembuatan keputusan (decision making).

Secara manajerial keberadaan keputusan akan menentukan masa depan suatu organisasi sekolah/madrasah. Suatu keputusan, apalagi keputusan strategis yang diambil pihak manajemen akan menentukan corak perilaku organisasi sekolah/madrasah dan tujuan pendidikan yang akan dicapai. Keberhasilan suatu organisasi sekolah/madrasah sangat bergantung pada tingginya mutu keputusan yang diambil oleh para top manajer

sekolah/madrasah tersebut. Pengambilan keputusan merupakan inti tugas kepala sekolah/madrasah sebagai manajer sekolah/madrasah.

\section{DESKRIPSI TEORITIK}

\section{A. Efektivitas Kepemimpinan}

konsep pemimpin yang efektif juga berbeda antara satu pakar dengan pakar lainnya. Yang pertama Penulis kemukakan pendapat Schermerhorn: "An effective manager is one whose organizational unit, group, or team consistently achieves its goals while members remain capable, committed, and enthusiastic. ( John R. Schermerhorn, James G. Hunt, and Richard N. Osborn, 2005:11). pemimpin efektif adalah yang unit organisasi, kelompok, atau timnya secara konsisten mencapai tujuannya sementara para anggotanya tetap memiliki kemampuan, komitmen, dan antusias/semangat).

Kemudian Susan E. Jackson, Randall S. Schuler, and Steve Werner berpendapat bahwa, "Effective leadership ensures that people are generally working to achieve the same 
results.'( Susan E. Jackson, Randall S. Schuler, and Steve Werner, 2009:56) kepemimpinan yang efektif memastikan/menjamin orang-orang secara umum mencapai hasil yang sama.

Hughes, Ginnett, and Curphy mengatakan bahwa "effective Leaders are individuals who are good at building teams and getting results"' Richard L. Hughes, Robert C. Ginnett, and Gordon J. Curphy, 2009:90). para pemimpin yang efektif adalah individu-individu yang bagus dalam membangun tim dan mencapai hasil. Selanjutnya George and Jones mengatakan, "Leader effectiveness is the extent to which a leader actually does help a group or organization achieve its goals." ( Jennifer M. George and Gareth R. Jones,2005:375) Efektivitas pemimpin adalah tingkat dimana seorang pemimpin benar-benar membantu kelompok atau organisasi untuk mencapai tujuannya.

Jadi Konsep efektivitas kepemimpinan sulit untuk didefinisikan maupun diukur, namun dapat diidentifikasi dari empat kriteria dari keefektifitas pemimpin tersebut, yaitu: tugas/pekerjaan pemimpin; kepribadian pemimpin itu sendiri; hubungan pemimpin dengan yang lain; dan pemimpin sebagai bagian dari organisasi.

\section{a. Perilaku Pemimpin Efektif}

Yukl mengatakan bahwa ada tiga jenis perilaku kepemimpinan yang dapat dibedakan antara manajer yang efektif dengan manajer tidak efektif, yaitu :

1) Perilaku yang berorientasi tugas. Para manajer yang efektif tidak menggunakan waktu dan usahanya dengan melakukan pekerjaan yang sama seperti bawahannya. Sebaliknya, para manajer yang lebih efektif berkonsentrasi pada fungsi-fungsi yang berorientasi pada tugas seperti merencanakan dan mengatur pekerjaan, mengkoordinasikan kegiatan para bawahan, dan menyediakan keperluan, peralatan dan bantuan teknis yang dibutuhkan. Di samping itu, para manajer yang efektif memandu para bawahannya dalam menetapkan sasaran kinerja yang tinggi, tetapi realistis.

2) Perilaku yang berorientasi hubungan. Bagi para manajer yang efektif, perilaku yang berorientasi tugas tidak terjadi dengan mengorbankan perhatian terhadap hubungan antar manusia. Para manajer yang efektif lebih penuh perhatian, mendukung, dan membantu para bawahan. Perilaku mendukung yang berkolerasi dengan kepemimpinan yang efektif meliputi memperlihatkan kepercayaan dan rasa dipercaya, bertindak ramah dan perhatian, berusaha memahami permasalahan bawahan, membantu mengembangkan bawahan dan memajukan karier mereka, selalu memberi informasi kepada bawahan, memperlihatkan apresiasi terhadap ide-ide bawahan, dan memberikan pengakuan atas kontribusi dan keberhasilan bawahan.

3) Kepemimpinan partisipatif. Para manajer yang efektif menggunakan lebih banyak supervisi kelompok daripada mengendalikan tiap bawahan sendiri-sendiri. Pertemuan berkelompok memudahkan partisipasi bawahan dalam pengambilan keputusan, memperbaiki komunikasi, mendorong kerjasama, dan memudahkan pemecahan konflik. Peran manajer dalam pertemuan kelompok yang utama adalah harus memandu diskusi dan membuatnya mendukung, konstruktif, dan berorientasi pada pemecahan masalah. Namun penggunaan partisipasi tidak menyiratkan hilangnya tanggung jawab, dan manajer tersebut tetap bertanggung jawab atas semua keputusan dan hasilnya (Gary Yuk, 2010:107). 


\section{b. Ciri/Sifat Pemimpin Efektif}

1) Achua and Lussier mengemukakan te Dominance (dominan). Dominan bukan berarti mereka "overly bossy" (berlagak bos) maupun bergaya penggertak (use a bullying style);

2) High Energy (energi tinggi). Tingkat energi yang tinggi membantu para manajer menanggulangi pekerjaan yang berat dalam pencapaian tujuan. Vitalitas yang tinggi dan keuletan emosional membuatnya lebih mudah untuk bertoleransi terhadap tekanan. Seorang pemimpin yang memiliki toleransi terhadap tekanan dan ketenangan yang tinggi akan lebih besar kemungkinannya untuk tetap tenang dan memberikan pengarahan yang mantap dan pasti kepada para bawahan dalam suatu krisis;

3) Self-Confidence (percaya diri). Para pemimpin yang memiliki rasa percaya diri yang tinggi akan lebih besar kemungkinannya untuk mencoba tugas yang sulit dan menetapkan sasaran yang menantang baginya. Optimisme serta kegigihan mereka dalam usahanya menyelesaikan tugas atau misi kemungkinan akan meningkatkan komitmen dari para bawahan, rekan sejawat, dan atasan untuk mendukung upaya tersebut;

4) Locus of Control (pusat kendali). Ciri lain yang terlihat relevan bagi efektivitas manajerial disebut locus of control (pusat kendali) yang diukur dengan skala kepribadian yang dikembangkan oleh Rotter (1996). Uraian lengkap tentang LOC ini peneliti paparkan pada variabel dua (X2) dalam penelitian ini;

5) Stability (kestabilan emosi). Para pemimpin harus mampu mengontrol emosinya. Para pemimpin yang memiliki kematangan emosional yang tinggi tidak akan membiarkan kemarahannya menimbulkan hal-hal yang buruk dan mereka memiliki lebih banyak hubungan kerjasama dengan para bawahan, rekan sejawat, dan atasan;

6) Integrity (integritas). Integritas berarti perilaku seseorang konsisten dengan nilai yang menyertainya, dan orang tersebut bersifat jujur, etis dan dapat dipercaya. Para pemimpin akan kehilangan kredibilitas bila orang menemukan bahwa mereka telah berbohong atau membuat pernyataan yang menyimpang dari yang sebenarnya;

7) Intelligence (kecerdasan). Kecerdasan mengacu pada kemampuan kognitif untuk berpikir kritis, menyelesaikan masalah, dan membuat keputusan. Ia juga mengacu pada kemampuan mental secara umum. Pekerjaan manajer membutuhkan kecerdasan yang tinggi dan para manajer pada umumnya memiliki tingkat kecerdasan di atas rata-rata;

8) Flexibility (fleksibilitas). Fleksibilitas mengacu pada kemampuan dalam menghadapi situasi yang berbeda. Para pemimpin harus berada di depan dalam menghadapi perubahan dunia, perubahan yang terus berlanjut dan bertambah. Oleh karena itu, para pemimpin yang efektif harus fleksibel dan mampu beradaptasi dengan situasi;

9) Sensitivity to Others (memiliki kepekaan terhadap yang lain). Para pemimpin efektif harus memiliki kepekaan terhadap yang lain. Mereka harus mampu memahami 
anggota kelompoknya sebagai individu-individu yang memiliki masalahnya masingmasing, dan bagaimana cara terbaik untuk berkomunikasi serta mempengaruhi mereka (Christopher F. Achua and Robert N. Lussier, 2010:33-37).

\section{c. Ketrampilan Pemimpin Efektif}

Yukl mengindentifikasikan sejumlah ketrampilan manajerial yang relevan, yaitu:

1) Technical Skills (Ketrampilan Teknis). Ketrampilan ini meliputi pengetahuan tentang metode, proses, dan perlengkapan untuk melakukan aktivitas khusus dari unit organisatoris manajer itu. Ketrampilan teknis juga meliputi pengetahuan faktual tentang organisasi (peraturan, struktur, sistem manajemen, karakteristik karyawan), dan pengetahuan tentang produk dan jasa organisasi (spesifikasi teknis, kekuatan dan keterbatasan). Jenis pengetahuan ini diperoleh dengan kombinasi antara pendidikan formal, pelatihan, dan pengalaman kerja;

2) Conceptual Skills (Ketrampilan Konseptual). Ketrampilan konseptual (atau "kognitif") meliputi kemampuan analitis, berpikir logis, membentuk konsep, pemikiran yang induktif, dan pemikiran deduktif. Dalam arti umumnya, ketrampilan konseptual termasuk penilaian yang baik, dapat melihat ke depan, intuisi, kreativitas, dan kemampuan untuk menemukan arti dan keteraturan dalam peristiwa yang tidak pasti dan ambigu. Ketrampilan konseptual telah diukur dengan sejumlah metode yang berbeda, termasuk tes kecerdasan, tes situasi, wawancara, dan peristiwa kritis;

3) Interpersonal Skills (Kecerdasan Antar Pribadi). Kecerdasan antar pribadi atau kecerdasan sosial meliputi pengetahuan mengenai perilaku manusia dan proses kelompok, kemampuan untuk mengerti perasaan, sikap serta motivasi dari orang lain; dan kemampuan untuk mengomunikasikan dengan jelas dan persuasif (Gary Yukl, 2010:62-64).

\section{d. Power (kekuasaan)}

Schermerhorn berpendapat bahwa kepemimpinan sangat membutuhkan power (kekuasaan). Sisi positif power, yaitu kekuasaan mempengaruhi dan mengendalikan orang lain untuk kebaikan kelompok atau organisasi, merupakan fondasi dari kepemimpinan yang efektif. Menurutnya (John R. Schermerhorn, 2010: 435-436) yaitu:

1) Reward Power (kemampuan mempengaruhi melalui penghargaan);

2) Coercive Power (kemampuan mempengaruhi melalui hukuman);

3) Legitimate Power (kemampuan mempengaruhi melalui kewenangan);

4) Expert Power (kemampuan mempengaruhi melalui keahlian. Maksudnya bahwa power itu diperoleh karena pengetahuan dan ketrampilan yang dimiliki pemimpin); dan

5) Referent Power (kemampuan mempengaruhi karena identitas diri. Maksudnya bahwa power itu diperoleh karena orang lain kagum dan ingin selalu dikenal baik oleh sang pemimpin). Reward power, coercive power, dan legitimate power diperoleh berdasarkan posisi yang dimiliki (position power), sementara expert power dan referent power diperoleh dari kualitas pribadi yang dimiliki (personal power). 


\section{B. Pengambilan Keputusan}

Pengambilan keputusan adalah kegiatan seseorang dalam kehidupan sehari-hari dan juga dalam dunia bisnis. Membuat keputusan membantu para manajer/pemimpin dalam mengidentifikasi dan menyeleksi kesempatan yang potensial, membantu mereka memecahkan masalah yang sedang dihadapi dan membuat masalah mendatang lebih mudah diatasi. Pembuat keputusan yang baik adalah mereka yang efektif dalam memproses informasi, menilai/menaksir resiko, dan membuat pilihan yang berdampak positif bagi organisasi. Para pemimpin harus mampu membuat keputusan. Bila mereka tidak mampu membuat keputusan, maka mereka tidak akan menjadi pemimpin yang efektif, sebagaimana dikatakan oleh Bateman and Snell, "Decisions. If you can't make them, you won't be an effective manager." (Thomas S. Bateman and Scott A. Snell, 2002:70) (Keputusan. Bila anda tidak mampu membuatnya, maka anda tidak akan menjadi manajer yang efektif).

Pengambilan keputusan menurut Williams adalah "The process of choosing a solution from available alternatives" ( Chuck Williams:2005:168) (sebuah proses memilih satu solusi dari beberapa alternatif yang ada). Pendapat senada diberikan oleh Schermerhorn, Jr., Hunt, Osborn: "Decision making is the process of choosing a course of action for dealing with a problem or opportunity." (Pengambilan keputusan adalah proses pemilihan sebuah tindakan untuk memecahkan suatu masalah atau kebutuhan). Sementara itu Fred Luthans mendefinisikan pengambilan keputusan sebagai "The process by which members of an organization choose a spesific course of action to respond to the opportunies and problems that confront them"( Fred Luthans, 2008:418419) (Pengambilan keputusan adalah sebuah proses yang dilakukan anggota organisasi dalam memilih tindakan yang spesifik untuk merespon kebutuhan-kebutuhan dan masalah-masalah yang mereka hadapi).

Dalam hal ini Pengambilan keputusan juga merupakan suatu proses yang disengaja yang terjadi dalam rangka membuat pilihan diantara beberapa alternatif dengan maksud untuk berpindah kepada keadaan yang diinginkan. Adapun langkahlangkah yang ditempuh dalam proses pengambilan keputusan menurut para ahli adalah sebagai berikut: (1) identity problem or opportunity (mengidentifikasi masalah atau kesempatan); (2) choose the best decision process (memilih proses keputusan terbaik); (3) develop alternative solutions (mengembangkan solusi-solusi alternatif); (4) choose the best alternative (memilih alternatif terbaik); (5) implement the selected alternative (menerapkan alternatif yang terpilih); (6) evaluate decision outcomes (mengevaluasi hasil keputusan).

Secara singkat Moorhead and Griffin berpendapat bahwa, "Decision making is choosing one alternative from among several". ( Gregory Moorhead and Ricky W. Griffin, 2010:192) pengambilan keputusan adalah memilih satu alternatif dari beberapa alternatif yang ada. Mereka mencontohkan dalam permainan sepak bola. Seorang gelandang dapat saja kemungkinan bermain dalam ratusan kompetisi. Dengan selalu berpikir untuk mencetak gol, dia akan memilih jalan permainan yang nampaknya menjanjikan hasil terbaik. Pilihannya itu didasarkan pada pemahamannya tentang situasi permainan, kemungkinan hasil yang bervariasi, dan preferensinya (pilihan) untuk masing-masing hasil tersebut. 


\section{Teori-teori yang Berhubungan dengan Efektiftivitas Kepemimpinan dalam Pengambilan Keputusan (Decision Making)}

1) Contingency Theory of Leadership (Teori Kontingensi)

Fiedler mengembangkan sebuah teori yang disebut "Contingency Model of Leadership Effectiveness". Model ini membahas tentang hubungan antara gaya kepemimpinan dan situasi yang tidak menyenangkan. Inti dari teori ini adalah bahwa dalam situasi yang sangat tidak menyenangkan, pemimpin yang efektif memegang kekuasaan dan membuat keputusan yang diperlukan untuk menyelesaikan tugas tanpa meminta masukan atau berusaha untuk tetap membuat semua orang suka. Fred Luthans (2008)

2) Charismatic Leadership Theory

Pemimpin karismatik memiliki kemampuan untuk menginspirasi dan memotivasi orang untuk melakukan sesuatu yang lebih dari biasanya, walaupun banyak rintangan dan pengorbanan dalam menentukan kebijakan. Richard L. Dalt (2009)

3) Transactional Leadership Theory

Perilaku pemimpin transaksional menunjukkan pertukaran atau transaksi antara pemimpin dan pengikut. Pertukaran dengan jalan pemimpin memutuskan dalam memberikan penghargaan untuk kinerja, usaha, dan partisipasi bawahannya. Timothy T. Baldwin, William H. Bommer (2008)

\section{4) Transformasional Leadership Theory}

Kepemimpinan transformasional meliputi antisipasi trend masa depan, menginspirasi pengikut agar memahami dan memiliki visi baru, mengembangkan orang untuk menjadi pemimpin atau pemimpin yang lebih baik, dan membangun organisasi atau kelompok ke dalam komunitas yang berani menghadapi tantangan. John W. Slocum, Jr. and Don Hellriegel (2007). Pemimpin transformasional menginspirasi pengikut agar tidak hanya percaya kepada pemimpin, namun juga percaya kepada potensi dirinya untuk menciptakan masa depan yang lebih baik bagi organisasinya. Richard L. Dalt (2009)

Sebagai tambahan, Yukl mengatakan bahwa kepemimpinan transformasional lebih meningkatkan motivasi dan kinerja pengikut dibandingkan dengan kepemimpinan transaksional, tetapi pemimpin yang efektif menggunakan kombinasi dari kedua jenis kepemimpinan tersebut.

Berdasarkan kajian teori di atas dapat disintesiskan bahwa efektivitas kepemimpinan adalah tingkat pencapaian pemimpin dalam melaksanakan tugas dan fungsinya pada suatu organisasi dengan menggunakan semua sumberdaya dalam mengambil suatu keputusan untuk mencapai tujuan organisasi yang telah direncanakan.

\section{KORELASI ANTARA EFEKTIFITAS KEPEMIMPINAN MADRASAH SEBAGAI PENGAMBILAN KEPUTUSAN}

Kepala Madrasah sebagai pimpinan selalu dihadapkan pada pengambilan keputusan untuk keberhasilan organisasi yang dipimpinnya. Pengambilan keputusan 
diperlukan karena sebagian besar pekerjaan yang dihadapinya harus didelegasikan kepada para guru dan staf tata usaha.

Pengambilan keputusan sebagai suatu rangkaian kegiatan atau proses dalam memilih berbagai alternatif, mengembangkan dan mengevaluasinya melalui penetapan berbagai kriteria hingga pada akhirnya dapat diambil keputusan terbaik yang menghendaki tingkat kemampuan yang tinggi dari seorang kepala madrasah. Bentuk keputusan yang diambil haruslah didukung oleh para guru dan staf administrasi lainnya, sehingga dapat dicapai tujuan pendidikan dan pengajaran di madrasah. Prosedur yang ditempuh oleh kepala madrasah dalam mengambil

Dalam korelasi antara efektivitas kepemimpinan dengan pengambilan keputusan, (Gery Yuk1, 2010:28) mengatakan:

Leader effectiveness is occasionally measured in terms of the leader's contribution to the quality of group processes, as perceived by followers or by outside observers. Does the leader enhance group cohesiveness, member cooperation, member commitment, and member confidence that the group can achieve its objectives? Does the leader enhance problem solving and decision making by the group, and help to resolve disagreements and conflicts in a constructive way?

Maksudnya bahwa beberapa peneliti mengukur efektivitas pemimpin berdasarkan kontribusi pemimpin pada kualitas proses kelompok yang dirasakan oleh para pengikut atau pengamat dari luar. Apakah pemimpin mampu meningkatkan kohesitas anggota kelompok, kerjasama anggota, motivasi anggota, penyelesaian masalah, pengambilan keputusan, dan mendamaikan konflik antar anggota.

Berdasarkan tulisan yang telah dijabarkan, Kepala Madrasah dalam membuat keputusan haruslah memanfaatkan berbagai sumber daya yang dimiliki yang merupakan faktor penentu pencapaian tujuan secara efektif dan efisien. Seringkali tujuan pendidikan dan pengajaran tidak tercapai karena keputusan yang diambil tidak mendukung pencapaian tujuan program yang telah dicanangkan. Keputusan yang diambil melalui langkah-langkah yang baik mulai dari penetapan tujuan sampai memilih alternatif terbaik untuk dilaksanakan akan berkontribusi pada efektifitas kepemimpinan kepala madrasah. Dengan demikian, jelaslah terdapat hubungan positif antara efektivitas kepemimpinan kepala madrasah dalam pengambilan keputusan akan menetukan kemajuan madrasah ke depan. Makin tinggi kemampuan pengambilan keputusan, makin efektif kepemimpinan kepala madrasah tersebut.

\section{PENUTUP}

Berdasarkan uraian tulisan di atas, untuk meningkatkan efektifitas kepemimpinan kepala Madrasah sebagai pengambil keputusan, dapat penulis simpulkan sebagai berikut :

1. Kepala Madrasah membuat perencanaan dan prosedur kerja, membangun kerjasama dengan para anggotanya untuk mencapai tujuan, dan senantiasa melakukan pengawasan dan pengembangan organisasi;

2. Kepala madrasah harus meningkatkan kemandirian dalam bekerja, memiliki kepercayaan terhadap diri sendiri, tekun dalam bekerja, tidak selalu bergantung 
pada lingkungan kerja, dan senantiasa aktif berpartisipasi dalam kegiatan organisasi;

3. Hal-hal yang harus diperhatikan oleh Kepala Madrasah Dalam pengambilan keputusan, diantaranya: senantiasa mengidentifikasi masalah yang ada, mempertimbangkan kekuatan dan kelemahan organisasi dalam menentukan dan mengevaluasi alternatif-alternatif pemecahan masalah, memilih alternatif pemecahan masalah yang terbaik, melaksanakan keputusan yang telah diambil, dan yang terakhir mengevaluasi pelaksanaan keputusan agar permasalahan yang timbul setelahnya lebih mudah diatasi. 


\section{DAFTAR PUSTAKA}

Chuck Williams, Management USA: Thomson South-Western,2005

Fred Luthans, Organizational Behavior, Eleventh Edition New York: McGraw-Hill/Irwin, 2008

Gary Yukl, Leadership in Organizations, Seventh Edition, New Jersey: Pearson Education, Inc., 2010

Gregory Moorhead and Ricky W. Griffin, Organizational Behavior: Managing People and Organizations, Ninth Edition China: South-Western, Cengage Learning, 2010.

Imran Siregar, Problematika Madrasah Era Otonomi Daerah Jakarta: Badan Litbang dan Diklat Departemen Agama RI, 2007

Jennifer M. George and Gareth R. Jones, Understanding and Managing Organizational Behavior New Jersey: Pearson Prentice Hall, 2005

John R. Schermerhorn, Introduction to Management, Tenth Edition Asia: John Wiley \& Sons (Asia) Pte Ltd, 2010

John R. Schermerhorn, James G. Hunt, and Richard N. Osborn, Organizational Behavior, Ninth Edition USA: John Wiley \& Sons, Inc.,2005

Mohammad Ali, “Mutu Madrasah Harus Terus Ditingkatkan,” Republika, 30 Januari 2011

Nunu Ahmad An-Nahidl, dkk., Posisi Madrasah dalam Pandangan Masyarakat, Jakarta: Puslitbang Pendidikan Agama dan Keagamaan, 2007

Richard L. Hughes, Robert C. Ginnett, and Gordon J. Curphy, Leadership, Enhancing the Lessons of Experience, sixth Edition New York: McGraw-Hill Education, 2009

Susan E. Jackson, Randall S. Schuler, and Steve Werner, Managing Human Resources, International Student Edition Canada: South-Western Cengage Learning, 2009

Thomas S. Bateman and Scott A. Snell, Management: Competing in the New Era New York: McGraw-Hill/Irwin, 2002 